\title{
Hollandia népegészségügyi rendszere és egészségfejlesztéssel foglalkozó szervezetei
}

\author{
The public health system and health promotion organizations \\ of the Netherlands
}

Szerzők: Túri Gergő $₫$, Kasza Katalin

Országos Közegészségügyi Intézet

Beküldve: 2018. 03. 09.

doi: $10.24365 /$ ef.v59i2.257

\begin{abstract}
Összefoglaló: A cikkben Hollandia népegészségügyi rendszerének és egészségfejlesztéssel foglalkozó szervezeteinek bemutatásán keresztül tanulságokat fogalmazunk meg a hazai egészségfejlesztési hálózat lehetséges továbbfejlesztési irányainak meghatározása érdekében. Röviden ismertetjük az egyes közigazgatási szintek és szervezetek főbb szerepét a népegészségügyi rendszerben, bemutatjuk a népegészségügyi rendszer kialakulását és múködését befolyásoló releváns stratégiákat és jogszabályokat, valamint összefoglaljuk az országos és közösségi szinten működő szervezetek feladatait és tevékenységeit. A holland egészségügyi rendszer a magán- és közfinanszírozott szolgáltatások keverékére épül, azonban a népegészségügyi szolgáltatásokat központi adóból finanszírozzák, így biztosítva az univerzális hozzáférést. A népegészségügyi beavatkozások közösségi összefogás, valamint gyakorta interszektoriális együttmúködések révén valósulnak meg. A közösségi egészségszolgáltatókat az önkormányzatok közösen múködtetik, ezáltal az önkormányzatok is nagyobb fokú együttmúködésre, partnerségek kialakítására ösztönözhetők. A közösségi egészségszolgáltatók négyévente egészségstratégiát készítenek, aminek során figyelembe kell venniük a közösségek szükségleteit és a nemzeti prioritásokat.

Kulcsszavak: népegészségügyi rendszer; egészségfejlesztés; Hollandia
\end{abstract}

Summary: In the article we present the lessons learned from studying the public health system and health promotion organizations of the Netherlands, to determine the possible directions for further development of the Hungarian health promotion network. We briefly describe the main roles of the public administration levels and organizations in the public health system, present relevant strategies and legislation affecting the development and functioning of the public health system, and summarize the tasks and activities of organizations at national and community level. The Dutch healthcare system is based on a mix of private and public-financed services, but public health services are financed from central taxes, ensuring universal access. Public health interventions are implemented through community involvement and often intersectorial co-operation. Community Health Services are jointly operated by local governments, so local governments can also be encouraged to perform greater cooperation and partnerships. Community Health Services prepare a health strategy every four years, taking into account the needs of communities and national priorities.

Keywords: public health system; health promotion; Netherlands 


\section{AZ EGYES KÖZIGAZGATÁSI SZINTEK ÉS FŐBB SZERVEZETEK SZEREPE A NÉPEGÉSZSÉGÜGYI RENDSZERBEN}

Hollandia egészségügyi rendszere egészségbiztosításon és irányított versenyen alapul, amelynek fontos részét képezik az egészségbiztositók (insurers), az egészségügyi szolgáltatók (providers), valamint az e szereplőket felügyelő Fogyasztói és
Piaci Hatóság (Dutch Competition Authority), Egészségügyi Hatóság (Dutch Health Care Authority) és az Egészségügyi Felügyelöség (Health Care Inspectorate). Az Országos Egészségügyi Intézet (National Health Care Institute) menedzseli az egészségbiztosítási rendszert. [1. ábra] A prevenciós szolgáltatások és a szociális segélyezés nem része az egészségbiztosításnak, ezeket általános adókból finanszírozzák. ${ }^{1}$

1. ábra: Az egészségfejlesztésben szerepet játszó szervezetek a holland népegészségügyi rendszerben

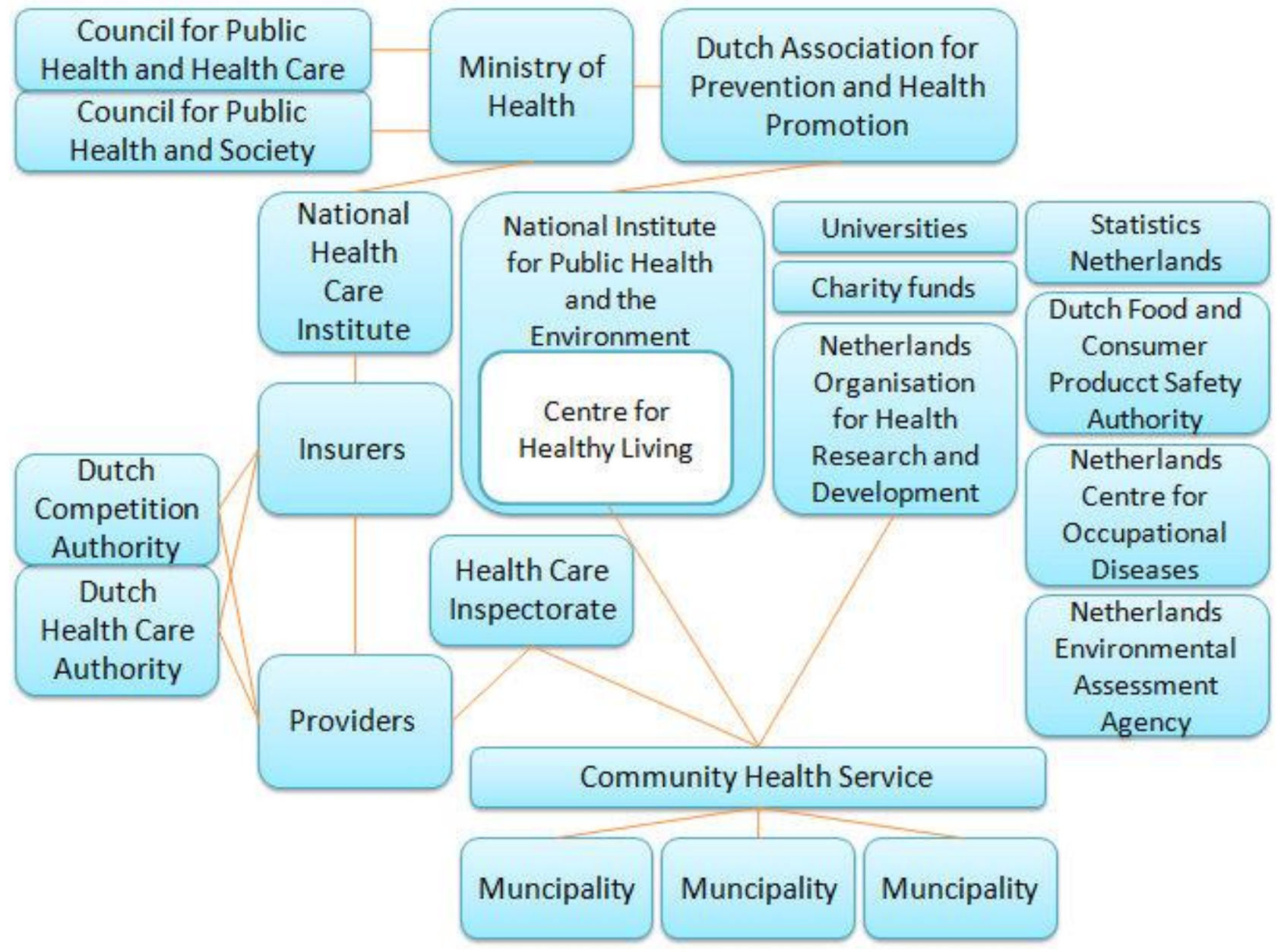

Forrás: Mossialos E et al. (2015) és saját kiegészítések²

Hollandiában két közigazgatási szinten azonosíthatók népegészségügyi szervezetek: országos szinten a fő irányító szerv a népegészségügyi stratégiát, prioritásokat megfogalmazó, jogszabály-változtatásokat kidolgozó Egészségügyi Minisztérium (Ministry of Health), valamint a kapcsolódó ágazatok minisztériumai. Az Egészségügyi Minisztérium munkáját a független Népegészségügyi és Egészségügyi Tanács (Council for Public Health and Health Care) és a Népegészségügyi és Társadalmi Tanács (Council for Public Health and Society) támogatják. Országos intézetek közé sorolható a kutatási, hatósági, tanácsadói, elemzési tevékenységeket végző Országos Népegészségügyi és Környezetvé- 
delmi Intézet (National Institute for Public Health and the Environment), valamint a hasonló profilú Egészséges Életmód Központ (Centre for Healthy Living) és a Holland Egészségfejlesztési Kutatóintézet (Netherlands Organisation for Health Research and Development). Országos szinten múködő szakmai szervezet a Holland Prevenciós és Egészségfejlesztési Szövetség (Dutch Association for Prevention and Health Promotion), amely a népegészségügyi szakemberek érdekképviseletében, képzésében és iránymutatások készítésében vállal szerepet. A Holland Statisztikai Hivatal (Statistics Netherlands) egészséggel kapcsolatos statisztikai adatokat gyüjt és elemez. A Holland Élelmiszer és Termékbiztonsági Hatóság (Dutch Food and Consumer Product Safety Authority) élelmiszer-egészségügyi feladatokat lát el. A Foglalkozási Megbetegedések Holland Központja (Netherlands Centre for Occupational Diseases), valamint a Holland Környezetvédelmi Ügynökség (Netherlands Environmental Assessment Agency) az egészség és az azt befolyásoló munkahelyi és környezeti tényezők kapcsolatával foglalkoznak.

Fontos szerepet töltenek be továbbá a jótékonysági szervezetek (charity funds) is, amelyek ugyancsak megfogalmaznak népegészségügyi célkitǔzéseket. A népegészségügyi szakemberek képzése, valamint az elméleti és gyakorlati kutatásokban való részvétel az egyetemek feladata.

A közösségi szinten múködő közösségi egészségszolgáltatók (Community Health Services) feladata a széleskörű népegészségügyi szolgáltatások nyújtása. A közösségi egészségszolgáltatókat a földrajzilag lehatárolt ellátási területükhöz tartozó önkormányzatok (muncipalities) közösen múködtetik. A közel 400 önkormányzatra 25 közösségi egészségszolgáltató jut, amelyeknek a tevékenységét az Egészségügyi Felügyelőség ellenőrzi.

\section{AZ INTÉZMMÉNYRENDSZER MŰKÖDÉSÉT MEGHA- TÁROZÓ JOGSZABÁLYOK ÉS STRATÉGIÁKK}

A 2006-ban elfogadott egészségbiztositási törvény (Healthcare Insurance Act) előírja, hogy minden olyan személy, aki Hollandiában él vagy dolgozik, köteles általános egészségbiztosítást kötni. ${ }^{3}$ A 2008ban elfogadott népegészségügyi törvény (Public
Health Act) határozza meg a közösségi egészségszolgáltatók és számos népegészségügyi intézet feladatait. A törvény kimondja, hogy a kormánynak és a közösségi egészségszolgáltatóknak négyévente népegészségügyi stratégiát kell megfogalmazniuk, valamint azt, hogy a nemzeti és a közösségi stratégiák célkitǔzéseit és akcióit össze kell hangolni. ${ }^{4}$

A 2014-ben elfogadott Nemzeti betegségmegelözési terv (National Prevention Plan) 2016-ig fogalmazott meg akciókat. ${ }^{5} A$ terv célja az egészségfejlesztés és egészségvédelem szerepének erősítése volt, ennek érdekében otthoni, iskolai és munkahelyi színtereken valósítottak meg akciókat hat minisztérium, valamint az önkormányzatok, számos gazdasági és civil szervezet együttmúködésével. A stratégia a sérülékeny társadalmi csoportok egészségének javitása érdekében közösségi összefogásra ösztönözte a különböző szereplőket. Célkitǔzésként szerepelt 850 „egészséges iskola” (Healthy School) kialakítása 2015-re, ahol csökken a túlsúlyos, fizikailag inaktív, dohányzó, alkoholfogyasztó fiatalok aránya. Az akciók között szerepelt a biztonságos és egészséges munkahelyi környezet kialakításának támogatása, valamint a fertőző megbetegedések megelőzésének támogatása.

A 2014-ben indult, Egészségesen a városban címú program (Healthy In The City Programme) a Nemzeti betegségmegelőzési terv részeként jött létre és 2018-ig tart. ${ }^{3}$ A program fő célja a különböző társadalmi csoportok közötti egészségegyenlőtlenségek mérséklése. A programba bevont 100 önkormányzat évente összesen 10 millió eurót kap arra, hogy közösségi szintű, komplex beavatkozásokat valósítsanak meg. A komplex programok célja a hozzáférhető egészségszolgáltatások biztosításának, az egészséges magatartás fejlesztésének és az egészséges természeti és épített környezet kialakításának támogatása.

\section{ORSZÁGOS SZINTEN MŰKÖDŐ SZERVEZETEK}

\section{Az egészségfejlesztésben szerepet játszó minisztériumok}

Az Egészségügyi Minisztérium felelős a népegészségügyért nemzeti szinten. Megfogalmazza a megelőzéssel és az egészségfejlesztéssel kapcsolatos szakpolitikai célkitǔzéseket, valamint javarészt 
felelős az országos büdzsé szétosztásáért a helyi önkormányzatok és az országos szervezetek között. A kormányzat operatív szerepe a szolgáltatások nyújtásában nagyon korlátozott, ezt a feladatot a magánszektor szereplőinek és a civil szervezeteknek delegálja.

A Pénzügyminisztérium (Ministry of Finance) az Adó- és Vámhivatalon (Tax and Customs Administration) keresztül közvetlenül felelős az egészségügyért, nemcsak a munkáltatói társadalombiztosítási járulékok, hanem az egészségügyi szolgáltatási járulék beszedésével is. ${ }^{1}$

Az Egészségügyi Minisztérium és más minisztériumok közötti ágazati együttmúködésre számos példa azonosítható. Az Egészségügyi Minisztérium mellett az Infrastrukturális és Környezetvédelmi Minisztérium (Ministry of Infrastructure and the Environment), az Oktatási Minisztérium (Ministry of Education), a Szociális Jóléti és Munkaügyi Minisztérium (Ministry of Social Welfare and Employment) és a Gazdasági Minisztérium (Ministry of Economic Affairs) is szerepet játszanak az egészségfejlesztés és a primer prevenció finanszírozásában. A minisztériumok együttes fellépése különösképpen az egészségvédelem terén valósul meg. Az egyes minisztériumok finanszírozzák a lokális hatóságokat, a kutatóintézeteket, az önkormányzati népegészségügyi szolgáltatásokat. Például a Gazdasági, Mezőgazdasági és Innovációs Minisztérium (Ministry of Economic Affairs, Agriculture and Innovation) felelős az élelmiszer minőségéért, a Szociális és Foglalkoztatási Minisztérium (Ministry of Social Affairs and Employment) a munkahelyi egészségfejlesztésért felel, az Egészségügyi Minisztérium finanszírozza az egészségvédelmet, a betegségek megelőzését és az általános egészségfejlesztéssel kapcsolatos tevékenységeket. ${ }^{6}$

\section{Országos intézetek}

Az Országos Népegészségügyi és Környezetvédelmi Intézet állami intézmény számos olyan funkcióval, mint a környezetvédelemmel vagy a népegészségügyi szakpolitikával kapcsolatos tanácsadás. A fertőző betegségek központi intézeteként ők szervezik a nemzeti vakcinációs programot. A betegségek megelőzésében részt vesz az élelmiszerminőség és a fogyasztói biztonság értékelésével. Továbbá gyógyszerészettel kapcsolatos tudást is generál, és szerepet játszik az új gyógyszerek befogadásában és bevezetésében. Az intézet négyévente közzéteszi a népegészségügyi helyzetjelentést és előrejelzéseit. Számos intézménnyel, kutatócsoporttal tart kapcsolatot, és átfogó képet tud mutatni az ország lakosságának egészségi állapotáról, az egészség, az egészségügy és az egészségpolitika meghatározóiról.

Az Egészséges Életmód Központ ösztönzi a különböző életmódbeli beavatkozások alkalmazását számos tervezési eszköz, kommunikációs anyag fejlesztésével, valamint az egészségfejlesztési beavatkozások minőségével, hatékonyságával és koherenciájával kapcsolatos információk bemutatásával. ${ }^{1}$

A kormány által finanszírozott megelőzést és egészségfejlesztést célzó kutatások folynak a Holland Egészségfejlesztési Kutatóintézetben és az egyetemeken, néha a helyi népegészségügyi szolgálatokkal együttmúködésben, valamint a betegségspecifikus pénzügyi alapoknál. A szervezet egyedülálló közvetítő és átfogó szerepet tölt be; finanszírozza az egészségügyi kutatásokat, és ösztönzi a tudás alkalmazását az egészségnyereség és a jobb egészségügyi ellátás érdekében. Rendszeresen ír ki pályázatokat a programjában szereplő projektek megvalósítására. Nyolc fő témával foglalkozik az intézet, ezek a hatékonyság, mentális egészség, a gyógyszerészet, az ellátás minősége, idősek, palliatív ellátás, prevenció és transzlációs kutatások. Az intézmény főbiztosa az Egészségügyi Minisztérium és a Holland Tudományos Kutatási Szervezet (Dutch Organization for Scientific Research).

A Holland Statisztikai Hivatal feladata az egészségre és jólétre vonatkozó statisztikai adatok gyűjtése, elemzése és közzététele. A hivatal feladata a mortalitási adatok gyúitése és elemzése is. A hivatal az általa gyűjtött információkat, valamint elemzéseket megosztja a kormányzat, a média, az oktatás és a privát szektor szervezeteivel.

A Holland Élelmiszer-és Termékbiztonsági Hatóság feladatai közé tartozik az élelmiszer-felügyelet, kockázatértékelés és kommunikáció. A szervezet monitorozza az egész termelési láncot az alapanyagoktól a kész termékekig, az állatok és növények egészségét, a fogyasztásra szánt termékek biztonságosságát, valamint regisztrálja az élelmiszer-szenynyezéseket és mérgezéseket.

A Foglalkozási Megbetegedések Holland Központjának feladata a foglalkozáshoz köthető megbetegedések nyilvántartása, ismeretterjesztő weboldal 
múködtetése, valamint a foglalkozási megbetegedések megelőzését célzó képzések és programok fejlesztése.

A Holland Környezetvédelmi Ügynökség többek között stratégiai elemzéseket, értékeléseket készít az egészség és a környezet kapcsolata, valamint ökológiai témákban. Az ügynökség támogatja a közigazgatási tervezést és döntéshozatalt azáltal, hogy azonosítja, elemzi és vitára bocsátja a globális felmelegedéssel, fenntartható fejlődéssel, levegőés vízminőséggel, urbanizációs folyamatokkal kapcsolatos kérdéseket és problémákat.

\section{Egyetemek}

Hollandiában számos egyetemen képeznek népegészségügyi szakértőket. Az Utrechti Egyetemen (Utrecht University) epidemiológusokat, az Amszterdami Vrje Egyetemen (Vrje University Amsterdam), valamint a Maastrichti Egyetemen (Maastricht University) az egészségfejlesztésben, betegségmegelőzésben, egészségpolitikában jártas szakembereket képeznek. Az Amszterdami Orvosi Oktatóközpont elsősorban az alapellátásban és a népegészségügy terén végez kutatásokat, főként a krónikus nem fertőző betegségeket és az öregedést vizsgálja. A szervezet Szociális Orvostudományi Tanszéke az egészség társadalmi meghatározóit, egészségfejlesztési stratégiákat és az egészségügy teljesítményét vizsgálja.

Független ellenőrző, tanácsadó szervezetek és testületek

Az Egészségügyi Felügyelet figyelemmel kíséri, ellenőrzi a közösségi egészségszolgáltatók teljesítményét, az ellátáshoz való hozzáférést és annak minőségét. A szervezet független az Egészségügyi Minisztériumtól, az egészségügyi miniszter tanácsadója. A szervezet vizsgálja az egészségügyi ellátással kapcsolatos baleseteket és panaszokat, és megteszi a megfelelő intézkedéseket. A felügyelet a gyermek-egészségügyi ellátás és gyermekvédelem terén együttmúködik a Holland Gyermekvédelmi Hatósággal (Dutch Inspectorate for Youth Care). ${ }^{1}$

A Népegészségügyi és Egészségügyi Tanács egy független testület, amely tanácsot ad a kormánynak az orvostudomány, az egészségügyi ellátás, a népegészségügy és a környezet-egészségügy terén.
A tanácsnak mintegy 170 tagja van, akik a különböző tudományágak képviselői. Hat központi témájuk az optimális egészségügy, a betegségmegelőzés, az egészséges táplálkozás, az egészséges életmód, az egészséges munkafeltételek, valamint az innováció és tudás infrastruktúrája.

A Népegészségügyi és Társadalmi Tanács független, kilenctagú tanácsadó testület, az Egészségügyi Minisztérium megbízásából készít egészségügyi és jóléti stratégiákat. Célja, hogy különböző perspektívákat mutasson be a változó társadalmi kontextusban.

\section{Jótékonysági szervezetek}

A betegségspecifikus pénzügyi alapoknak vagy jótékonysági szervezeteknek, mint például a Holland Szivalapitványnak (Dutch Heart Foundation) és a Diabéteszalapítványnak (Diabetes Foundation) is vannak egészségfejlesztési céljai és tevékenységei. Számos alapítvány az Együttmüködő Egészségpénztárak (Collaborating Health Funds) nevű ernyőszervezetben egyesült.

\section{Szakmai szervezetek}

Valamennyi egészségügyi szakma saját szervezettel, társulással, vagy kollégiummal foglalkozik a szakmai érdekek képviseletével, valamint hozzájárul a tudományos fejlődéshez. E szakmai szervezetek száma több mint százra tehető. Az anyagi érdekek védelme mellett ezek a szervezetek aktív szerepet játszanak a szakmai fejlődésben, a továbbképzésben, az iránymutatások kidolgozásában és általánosságban a tagok által nyújtott ellátás minőségének fejlesztésében. Erre példa a népegészségüggyel és betegségmegelőzéssel foglalkozó ernyőszervezet, a Holland Prevenciós és Egészségfejlesztési Szövetség (Dutch Association for Prevention and Health Promotion). ${ }^{4}$

\section{Gazdasági szervezetek}

Kereskedelmi, gazdasági szereplők, szervezetek (köztük a köz- és magánszféra közötti partneri kapcsolatok) is szerepet játszanak az egészségfejlesztés és az elsődleges prevenció finanszírozásában és megvalósításában. 


\section{KÖZÖSSÉGI SZINTEN MŰKÖDŐ SZERVEZETEK}

A közösségi szintû egészségfejlesztési tevékenységeket a holland népegészségügyi törvény szabályozza. Kimondja, hogy minden holland önkormányzat feladata a lakosság egészségének védelme, megőrzése és fejlesztése, ennek keretében az önkormányzatoknak négyévente népegészségügyi tervet kell készíteniük. Az önkormányzatok törvényben rögzített népegészségügyi feladatai: gyermekegészségügyi ellátás; környezet-egészségügy; egészség-tanácsadás; időszakos közegészségügyi ellenőrzés; menedékkérők egészsége; szürés; epidemiológia; egészségnevelés; közösségi mentális egészség. A jogszabályban meghatározott felada- tok számossága együttmúködésre, vagy akár egyesülésre készteti a feladatok ellátásához mérten sok esetben kis méretű önkormányzatokat annak érdekében, hogy biztosítani tudják a megfelelő szolgáltatásokat és a szolgáltatások végzéséhez szükséges szakértelmet. A törvényben említett feladatokat minden földrajzilag lehatárolt régióban egy közösségi egészségszolgáltató (Community Health Service - röviden: CHS) valósítja meg, amit az ellátási területéhez tartozó önkormányzatok közösen múködtetnek. Jelenleg 25 közösségi egészségszolgáltató múködik Hollandiában, amelyeket összesen 400 önkormányzat tart fenn [2. ábra]. Egy-egy CHS-hez 500-900 ezer fős lakosság tartozik.

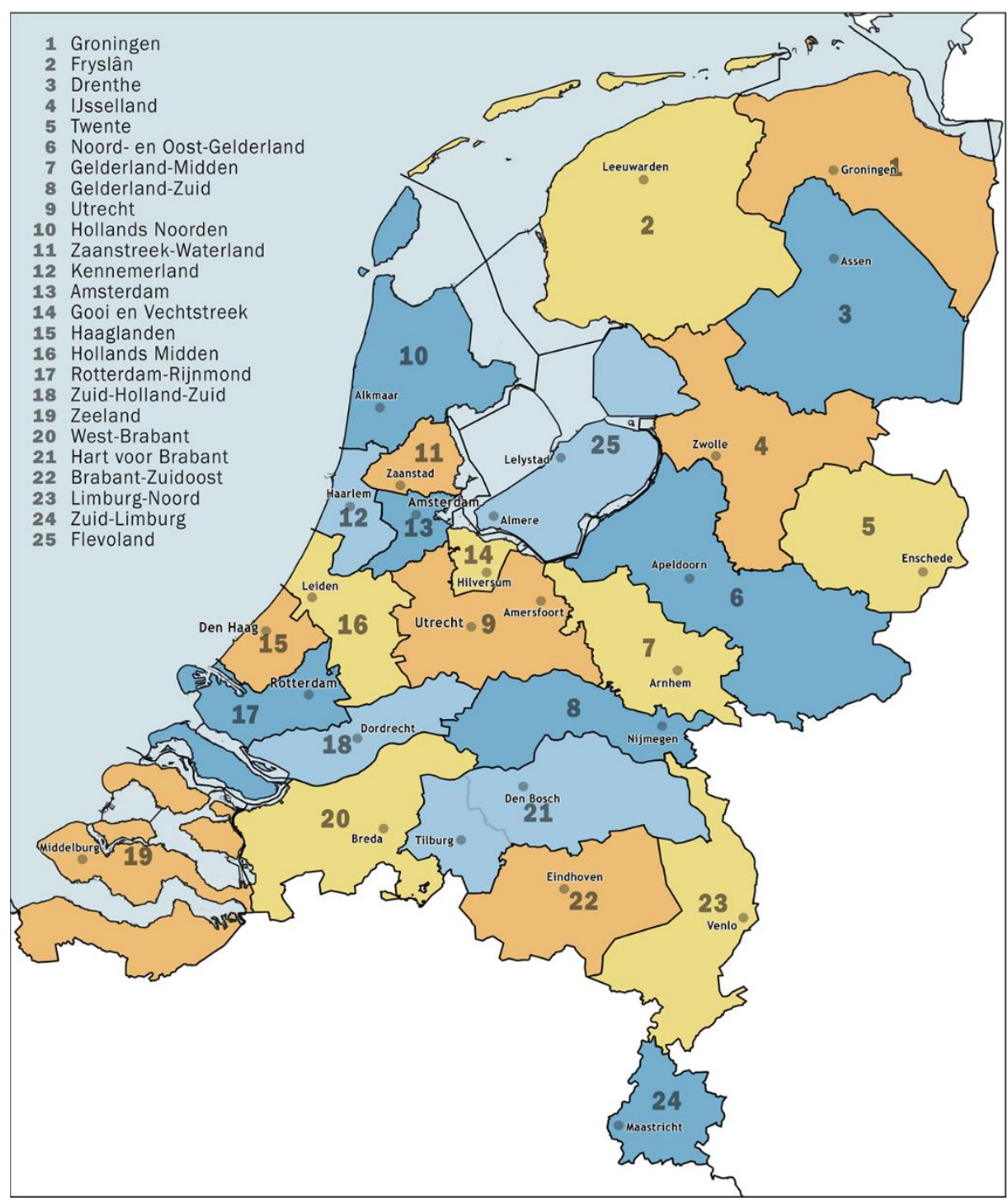

Forrás: ggd.nl 
A feladatok köre különbözhet a CHS-ek között, mivel minden önkormányzat saját prioritásokat fogalmaz meg számukra, amelyeket a települési önkormányzatok stratégiai dokumentumai tartalmaznak. A CHS-ek kidolgoznak és megvalósítanak olyan egészségfejlesztési programokat, amelyek a helyi közösségek igényeihez igazodnak. Olyan programokról van szó, mint amelyek pl. a gyermekkori elhízást, a túlzott alkoholfogyasztást vagy a cukorbetegséget célozzák. Emellett olyan beavatkozásokat is végrehajthatnak, melyeket országos szintű egészségfejlesztési intézetek terveztek.

A CHS-ek fontos szerepet töltenek be a kutatásban is, mivel munkavégzésük során együttmúködnek holland és külföldi egyetemekkel. Az Amszterdami Egyetemmel strukturális együttmúködés folyik az Akadémiai Együttmüködési Központokban.

\section{Példa: az Amszterdami Közösségi}

\section{Egészségszolgáltató}

Az Amszterdami Közösségi Egészségszolgáltató (Amsterdam Public Health Service) az egyik legnagyobb és legrégebbi CHS Hollandiában, széles körû népegészségügyi szolgáltatásokat nyújt. Működési területe Amszterdam, Amstelveen, Uithoorn, Ouder-Amstel, Diemen és Alsmeer, összesen 900 ezer fös populációval [3. ábra]. ${ }^{7}$ A régióban több mint 40 épületben, több mint 1200 alkalmazott foglalkozik népegészségügyi feladatokkal a lakosság egészségének javítása és fejlesztése céljából, amely a települések lakosságainak igényeire fókuszál. Különös figyelmet fordítanak az etnikai kisebbségekre, a szenvedélybetegekre, a hajléktalanokra és a szexmunkásokra.

A szervezet tevékenységei közé tartozik többek között a betegségek vagy fertőzések kockázati csoportjainak feltérképezése, vakcinációs kampányok szervezése, katasztrófák esetén a segítségnyújtás koordinációja, a viselkedést és az egészséget meghatározó tényezők befolyásolása, prevenciós programok megvalósítása különböző témákban (egészséges életmód, táplálkozás, megelőzhető betegségek).

$\mathrm{Az}$ amszterdami CHS négyévente átfogó felmérést végez az amszterdami népesség egészségi állapotáról és általános jólétéről (Health Monitor). A felmérés eredményeit az önkormányzat stratégiai terveiben használják fel. A népegészségüggyel kapcsolatos kutatási anyagok, riportok, cikkek, digitális és nyomtatott könyvek, magazinok elérhetők a Dokumentációs és Információs Központban (Documentation and Information Centre).

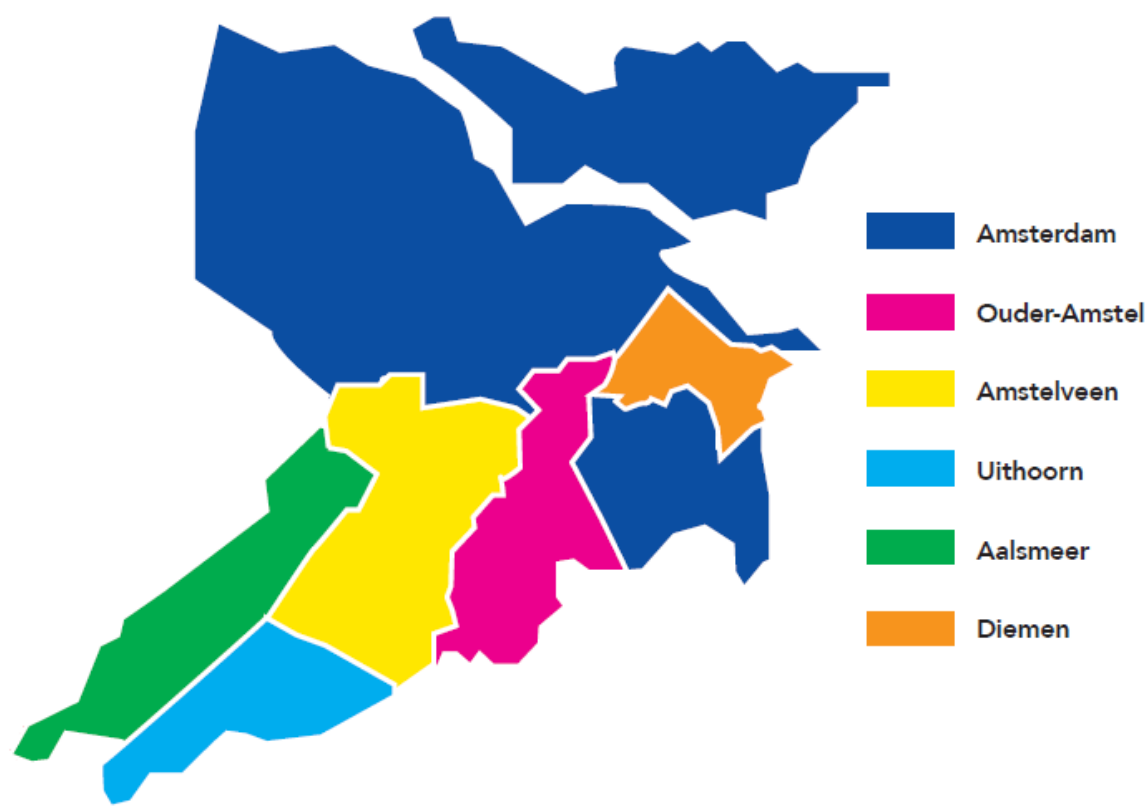


TANULSÁGOK A HAZAI NÉPEGÉSZSÉGÜGYI RENDSZER TOVÁBBFEJLESZTÉSÉHEZ

A holland egészségügyi rendszer a magán és közfinanszírozott szolgáltatások keverékére épül, azonban a népegészségügyi szolgáltatásokat központi adóból finanszírozzák, így biztosított az univerzális hozzáférés. Meglehetősen sok kormányzati intézmény foglalkozik az egészségügyi és népegészségügyi területek szabályozásával, felügyeletével országos szinten, ami arra utal, hogy egy-egy intézmény specifikus funkciót tölt be, jól definiált célrendszerrel múködik, és ez a teljesítményének mérése szempontjából kedvező. Számos országos szervezet foglalkozik a népegészségügyi kutatásokkal és a népegészségügyi szakemberek képzésével, az egészségfejlesztéssel kapcsolatos tudás és ismeretek terjesztésével. Fontos szerepet töltenek be a rendszerben a tanácsadó szervezetek, valamint Angliához hasonlóan Hollandiában is számos olyan jótékonysági szervezet, alapítvány múködik, amely egészségfejlesztéssel kapcsolatos célkitǔzéseket fogalmazott meg. Pozitívumként említhető, hogy a minisztériumok jellemzően együttmúködnek az egészséget érintő kérdésekben, ami elősegíti az interszektorális, ágazatokon átívelő egészségfejlesztési szemlélet megvalósulását a döntéshozatalban. A népegészségügyi beavatkozások közösségi összefogás, valamint gyakorta interszektorális együttmúködések révén valósulnak meg. A közösségi egészségszolgáltatókat az önkormányzatok közösen múködtetik, ezáltal az önkormányzatok is nagyobb fokú együttmúködésre, partnerségek kialakítására ösztönözhetők. Fontos tapasztalat, hogy a közösségi egészségszolgáltatók négyévente egészségstratégiát készítenek, és ennek során figyelembe kell venniük a közösségek szükségleteit és a nemzeti prioritásokat. A szolgáltatások minőségét és a szolgáltatók teljesítményét az Egészségügyi Minisztériumtól független szervezet felügyeli és ellenőrzi. A közösségi egészségszolgáltatók által megvalósított népegészségügyi beavatkozások beszámolói digitális és nyomtatott formában is elérhetők a Dokumentációs és Információs Központban, így biztosítva a rendszer transzparens múködését.

A tanulmány az EFOP-1.8.0-VEKOP-17-2017-00001 Egészségügyi ellátórendszer szakmai módszertani fejlesztése projekt keretein belül készült.

\section{HIVATKOZÁSOK}

\footnotetext{
${ }^{1}$ Kroneman M, Boerma W, van den Berg M, et al. Health system review. Netherlands. Health Systems in Transition. 2016; Vol. 18 No. 2. http://www.euro.who.int/_data/assets/pdf_file/0016/314404/HIT_Netherlands.pdf Elérve: 2018. 04.04.

${ }^{2}$ Mossialos E, Wenzl M, Osborn R, et al. International profiles of health care systems. 2015 http://www.commonwealthfund.org/ /media/files/publications/fund-report/2016/jan/1857_mossialos_intl_profiles_2015_v7.pdf?la=en Elérve: 2018. 04. 04.

${ }^{3}$ Hamberg-van Reenen HH, van Dale D, van Gils PF, et al. Good Practice in the Field of Health Promotion and Primary Prevention, The Netherlands Country Review. 2015 http://chrodis.eu/wp-content/uploads/2015/07/150708Netherlands-CHRODIS-final-draft-correctie-voor-website2.pdf Elérve: 2018. 04. 04.

${ }^{4}$ National Institutes of Health: Report of the Director National Institutes of Health. 2012 https://report.nih.gov/pdf/NIH_Biennial_Report_2012.pdf Elérve: 2018. 04. 04.

${ }^{5}$ National Institute for Public Health and the Environment: Dutch National Prevention Program. Everything is health. 2014-2016 https://ec.europa.eu/health//sites/health/files/social_determinants/docs/ev_20140124_co05_en.pdf Elérve: 2018. 04. 04.

${ }^{6}$ National Association of County and City Health Officials: National profile of Local Health Departments. 2016 http://nacchoprofilestudy.org/wp-content/uploads/2017/10/Summary_Report_Oct2017_Final.pdf Elérve: 2018. 04. 04.

${ }^{7}$ Amsterdam Public Health Service: GGD Amsterdam leaflet. 2014 www.ggd.amsterdam.nl/publish/.../algemene_brochure_ggd_engels.pdf Elérve: 2018. 04.04.
} 